\title{
The Impact of Social Responsibility Disclosure on Financial Performance Via Accounting Conservatism as A Mediator Variable: Evidence from Jordan
}

\author{
Mohammad Abdullah Fayad Altawalbeh ${ }^{1}$ \\ ${ }^{1}$ Business Faculty, Accounting Department, Tafila Technical University, Tafila, Jordan \\ Correspondence: Mohammad Altawalbeh, Business Faculty, Accounting Department, Tafila Technical University, \\ Tafila, Jordan. E-mail: Tawalbeh@ttu.edu.jo
}

Received: November 3, 2021

doi:10.5539/ijbm.v16n12p101
Accepted: November 16, $2021 \quad$ Online Published: November 17, 2021

URL: https://doi.org/10.5539/ijbm.v16n12p101

\begin{abstract}
This study aimed to investigate the direct effect of corporate social responsibility disclosure (CSRD) on financial performance as well as the indirect impact via accounting conservatism as a mediator variable. The sample of the study consisted of 45 industrial companies listed on Amman stock exchange (ASE) over the period 2015-2019, CSRD was measured using a 43-item index, data to measure the variables was collected through the financial reports of the study sample publicly available on ASE website, Smart PLS3 software was run to examine the study hypotheses, the results of the path analysis revealed that CSRD has a positive significant direct effect on financial performance, furthermore, accounting conservatism has a positive and significant effect on financial performance, this result prove that accounting conservatism has a complimentary partial mediation role between CSRD and financial performance, a partial mediation occurs when the direct impact of the exogenous (CSRD) remains significant along with the indirect impact in the mediation model, furthermore, it is a complementary mediation that occurs when the indirect effect and direct effect remain significant and in the same direction. The study recommends that external auditor evaluate and communicate the CSRD level within the auditor's report.
\end{abstract}

Keywords: corporate social responsibility, partial mediation, accounting conservatism, financial, path analysis, performance

\section{Introduction}

Corporate social responsibility (CSR) is the act of a firm to integrate social and environmental concerns while conducting its operations, accordingly, firms are not only profit oriented, but also consider social and environmental interests (Marta,2015), These interactions take place through different channels; the most important one is the corporation's annual report which is used as a mean to influence society's perception of their operations, and to legitimize their ongoing existence (Deegan \& Unerman,2011,p231). Although disclosure of social responsibility practices is often voluntary, it still attracts The interest of a large number of researchers in accounting literature to know the motive behind the corporate social practices, and what CSR actually means for an organization (Babalola, 2012), CSR practices can be considered as a good business sense even ends in an competitive advantage, CSR practices should be offered to all stakeholders to enable them to make rational decisions, and if we believe that companies disclose their social responsibility practices in order to gain the trust and support of the society and legitimize their activities, the question remains, do these CSR practices have any impact on the performance of companies? During the past decade, Researchers have provided abound studies to answer the former question, a lot of CSR studies have been done within the developing countries context, while evidences from developed countries still limited (Wahba \& Elasayed, 2015). Although Jordan is one of the developing countries, it keeps pace with international practices that seek to enhance the level of disclosure and transparency. In this context, Amman stock exchange market (ASE) has joined the united nations initiative for sustainable markets, accordingly; ASE attaches high priority to social stability and encourages listed companies to consider social and environmental activities and to protect human rights, interests of the society and future generations. Previous studies conducted in the Jordanian context have had interesting contribution in tracking the rapid development in the field of social responsibility practices and disclosure (e.g. Suwaidan et al., 2004, Weshah et al., 2012, Abu farha \& Alkhalaileh, 2016) this study intends to contribute to the literature in two ways; firstly, this paper will examine the direct and indirect impact of corporate social responsibility disclosure on 
financial performance using accounting conservatism as a mediator variable, Secondly; this paper will add to the literature by providing empirical evidence from a developing country.

The rest of the paper is structured as follows; the second part presents literature review and the study hypotheses, the third part presents the research method and design, the fourth part introduces the results, and the fifth part concludes the paper.

\subsection{Significance of the Study}

Despite the great interest in examining the association between CSR disclosure and firms' financial performance, the bulk focused on the direct impact of CSR disclosure on financial performance, the current study seeks to contribute to fill this gap by providing evidence from a developing country about the indirect impact of CSR disclosure on financial performance via accounting conservatism. Furthermore, this paper intends to examine the direct impact of CSR disclosure on financial performance using a manually constructed CSR disclosure score.

\subsection{The Objectives of the Study}

This paper has two main objectives, firstly; to examine the direct impact of CSR disclosure on financial performance, secondly; to examine the indirect impact of CSR disclosure on financial performance through accounting conservatism as a mediator variable. This paper is designed to extend the previous studies by examining the role of accounting conservatism on the relationship between CSR disclosure and financial performance. This study is designed to provide significant implications to investors, legislators, corporate management and researchers.

\section{Theoretical background and hypotheses development}

Previous studies have examined the notion of corporate social responsibility (CSR) from different views as this notion overlaps with other concepts such as standards of ethics, environmental responsibility and sustainability (Alsamman \& Alnashmi, 2016). Researchers have relied on a number of theories that justify the reasons for companies to engage and report CSR activities. Legitimacy theory argued that the acceptance and satisfaction of the society not only is seen as a resource for the entity, but also a key factor supporting the going concern by enhancing society's satisfaction and the level of being legitimate. Legitimacy theory depends on the notion of social contract that allows the entity to use the available resources as long as it conforms in its operations with the norms and expectations of the society (Deegan \& Unerman, 2011, p. 325). The stakeholders' theory argues that stakeholders are all parties who affect and are affected by the company's operations, and this is not limited to the shareholders only, This theory also argues that the objective of the company is not limited to maximizing owners' wealth, but extends to serve the external parties affected by the company's operations While the signaling theory assumes that successful companies usually send signals by reporting CSR activities to achieve a competitive advantage over other companies, and that management may disclose CSR activities in order to improve the management's reputation and obtain incentives and rewards (Babalola, 2012). This study takes the position of the stakeholders' theory that defines stakeholders as all parties that affect and affected by company's operations.

\subsection{The Impact of CSR Disclosure on Firms' Financial Performance}

Babalola (2012) Investigated the relationship between CSRD and financial performance in Nigerian companies for the period 1999-2008, the findings showed that Companies spend less than $10 \%$ of the income on social initiatives, while regression results showed a positive relationship between CSR disclosure and profitability. Angelia and Suryaningsih (2015) investigated the effect of social and environmental disclosure on performance, the results revealed a significant positive impact of disclosing environmental activities on ROA and ROE, while social responsibility disclosure exerts a positive and significant impact on ROE only. Gangi et al. (2018) used the agency theory to investigate whether CSR disclosure level has any impact on financial performance, the sample consisted of a group of European banks for the period 2009-2015, the results showed positive impacts of CSR disclosure on financial performance. Manrique and Ballester (2017) analyzed the effect of environmental activities on profitability during the global financial crisis. The study sample consisted of 2,982 companies for the period 2008-2015, the results revealed that the adoption of environmental activities will positively affect the profitability of companies in both developed and developing countries, but this effect was stronger in developing countries than in the developed countries. Madaleno and Vieira (2020) examined the effect of environmental disclosure quality of the listed firms in Spain and Portugal covered the period 2010-2017. The researchers added the gender variable as a governance dimensions besides the sustainability indicators, the results found that the presence of women in the board of directors leads to an increase in financial performance, and that sustainability practices enhance the financial position of the company. Oyewumi et al. (2016) examined the importance of 
reporting investments in social initiatives and disclosing those social responsibility practices. The results showed that carrying out social activities without disclosing them will have a poor impact on financial performance. Wuttichindanon (2017) examined the reporting alternatives for CSR disclosure and its determinants for the listed firms in Thailand, the study include governmental ownership, corporate size, age and financial performance as independent variables, the results found that government firms with high government ownership percentage and big firms are expected to adopt sustainability report, furthermore, content analyses of CSRD has a positive association with the government owner ship, which is consistent the view of stakeholder theory which believes that CSR activities are adopted because of the stakeholders power a part from financial performance. Platonova et al. (2016 ) Examined the existence of any association between reporting CSR activities and Financial performance for Islamic banks in Gulf cooperation council over the period 2000-2014, The results found a positive and significant association between reporting CSR activities and Financial performance. In the Jordanian context. Abu farah and Alkhalaileh (2016) analyzed the association between CSR disclosure and firms Financial performance using accounting and Market based measures Covers the period 2006-2011. The findings suggested a significant positive association between CSRD and financial performance measures. Suwaidan et al. (2004) Investigated the impact of disclosing social and environmental activities through the financial reports of the manufacturing companies listed on Amman stock exchange, the study conducted a manual content analysis to build the disclosure index. The findings found that on average company discloses 13 percent of the 37- items index. The regression results indicated that profitability and risk are positively and significantly associated with CSR disclosure. In the same context. Weshah et al. (2012) investigated the effect of reporting CSR activities on profitability in the Jordanian banking sector, the results found a positive association between reporting CSR activities and profitability. Depends on the above literature and to examine the direct effect of CSR disclosure on financial performance, the first hypothesis can be formulated as follows:

\section{H1: There is appositive and statistically significant effect of CSR disclosure on the financial performance}

\subsection{The Impact of CSR Disclosure on Accounting Conservatism}

Accounting conservatism is one of the important principles of accounting. According to (Basu,1997) accounting conservatism is reporting bad news in earnings faster than reporting good news, previous studies have examined the association between corporate social responsibility and accounting conservatism. Guo et al. (2020) investigated the association between corporate social responsibility and the choices of conservative accounting, the results showed an opposite association between conservative accounting and socially oriented firms. Hong (2020) analyzed the relationship between sustainability management and conservative accounting, the study used ESG index to measure sustainability management, the results revealed that ESG performance is negatively related to conservative accounting. Park and Ha (2020) examined the association between social and environmental practices and earnings transparency; the results revealed that reporting social and environmental practices is positively related to earnings transparency, which enhances market confidence. Bozollan et al. (2015) examined the relationship between CSR orientation and earnings management, the sample consisted of 1141 firms from 24 countries; the results revealed that CSR orientation minimize earnings management practices. Depends on the above literature the second hypothesis is:

\section{H2: There is a positive and statistically significant effect of CSR disclosure on accounting conservatism.}

\subsection{Conservative Accounting and Its Effect on Financial Performance}

El-Habashy (2019) examined the association between conservative accounting and financial performance. The sample of the study included 40 non-financial of Egyptian companies. Three indicators were used to measure financial performance namely is ROE, ROA and Tobins- Q. The results found that conservative accounting positively affects the financial performance measures. Sana'a (2016) examined the effect of conservative accounting on indicators of financial performance, the study sample consisted of 12 insurance companies listed on Amman stock exchange, financial performance was measured using earnings per share and ROA, the study concluded that accounting conservatism positively and significantly impacts the indicators of financial performance. A high degree of conservative accounting is expected to attract long term investors and creditors this in turn will enhance the firm's financial performance, moreover, conservative accounting decreases the management ability to practice opportunistic behaviors by restricting accounting policies and methods. Based on the above literature, the third hypothesis can be formulated as follows:

H3: There is a positive and statistically significant effect of accounting conservatism on financial performance

\subsection{The Impact of CSR Disclosure on Financial Performance through Mediation Variables}


Some Previous studies have addressed the indirect impact of reporting social and environmental practices on financial performance by including mediation variables such as Corporate governance, earnings management, ownership structure. Mahrani and Noorlailie (2018) examined the effect of CSR disclosure governance attributes on financial performance via earnings quality as a mediation variable measured by the modified Jones model (1995), the study sample consisted of 102 listed companies in Indonesia using a purposive sampling model, secondary data was collected through financial reports and audited financial statements publicly available, data was analyzed using Partial least square, the results revealed that earnings management has fully mediated the effect of CSR disclosure on financial performance, the indirect effect analysis showed that CSR disclosure positively affect earnings management, furthermore, earnings management has a negative and significant impact on financial performance. In addition, the results found a partial mediation role of earnings management between good governance and financial performance. Ner and Machdar (2019) investigated whether CSR disclosure has any mediating role between firm's governance and financial performance. The study sample consisted of Indonesian firms listed in the LQ 45 index covered the period 2011-2017. The study concluded that governance does not impact CSR disclosure, nor does it impact the financial performance. The results also failed to prove that CSR has a mediation role between governance and financial performance. Amake and Akogo (2021) examined the impact of reporting CSR activities and accruals earnings management, the study sample consisted of 20 industrial companies over the period 2013-2019, the results found that CSR disclosure positively impacts earnings management practices. The results also found that firms with higher CSR disclosure have higher accruals quality. Goncalves et al. (2021) examined the association between practicing earnings management and CSR disclosure. The sample of the study consisted of 568 companies for the period 2010-2018; earnings quality was measured using the modified Jones model (1995). The results found a negative relationship between corporate social disclosure and earnings management; Therefore, managers of high CSR disclosure are more committed to professional ethics, the study of Shen et al. (2019) examined the effect of CSR disclosure on conservative accounting. The study sample consisted of a group of Chinese companies and for the period 2010-2018, the results showed that CSR practices positively affect the level of accounting conservatism. These effects were positively reflected on the market reaction by attracting investments. In order to investigate the indirect impact of CSR disclosure on financial performance via accounting conservatism, the following hypothesis should be tested:

H4: There is a positive significant impact of CSR disclosure on financial performance via accounting conservatism as a mediator variable.

\section{Research Methodology}

The aim of this study is to investigate the direct and indirect impact of CSR disclosure on firm's financial performance via accounting conservatism as a mediator variable. Therefore, the appropriate model is to use the partial least square modeling (PLS-SEM), which depends on constructing two basic models namely are the structural (inner) model and the (outer) or measurement model. The structural model represents the basic variables, which are divided into two types: endogenous and exogenous variables, endogenous variables are variables that serve as dependent and/or independent variables while exogenous variables are variables that serve as independent variables only. More specifically, this study will use only one mediation variable, which is known as a simple mediation. The mediation role can be divided into two main types: full mediation and partial mediation; the full mediation appears when the indirect effect remains statistically significant while the direct effect is not. The partial mediation occurs when the direct and indirect effect remain statistically significant. Furthermore, if both direct and indirect effects have the same direction of effect, this is called complementary mediation. But if the direct and indirect effects are opposite to each other, then this is called a competitive mediation (Hair et.al, 2021)

Figure 1 illustrates the study model, and table 1 presents the variables' identification. 


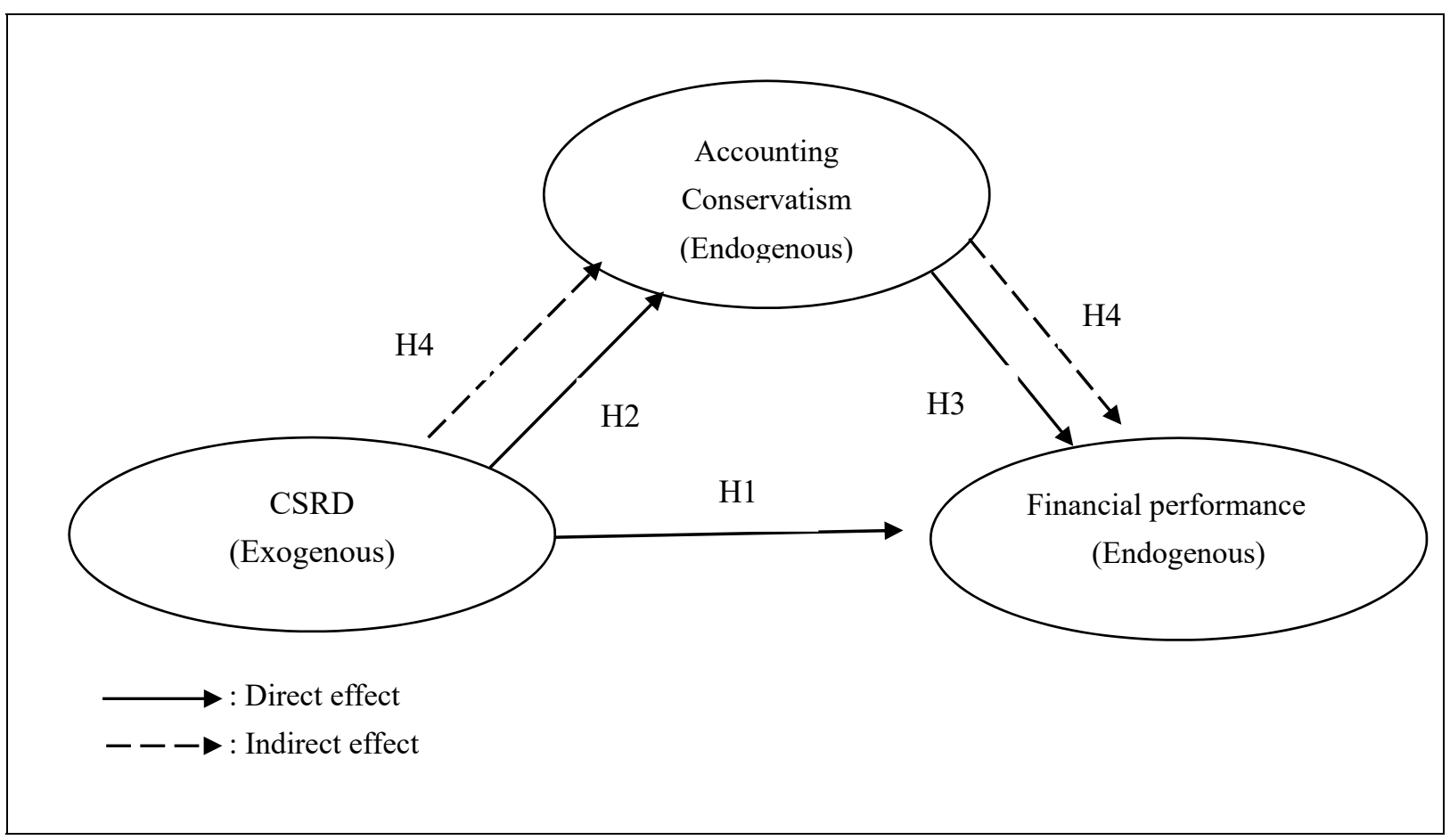

Figure 1. The path model

Table 1. Variables of the path model

\begin{tabular}{llll}
\hline Hypothesis & Independent & Mediation & Dependent \\
\hline$H 1$ & CSRD & & Financial performance \\
$H 2$ & CSRD & & Accounting conservatism \\
$H 3$ & Accounting conservatism & & Financial performance \\
$H 4$ & CSRD & Accounting conservatism & Financial performance \\
\hline
\end{tabular}

\subsection{Sample, Data and Variables Measurement}

The study population consisted of all manufacturing companies listed on Amman stock exchange (ASE) for the period 2015-2019. The study excluded companies experienced losses, companies listed in the third market, companies with missing data related to the variables measurements; the final sample consisted of 45 manufacturing company. Data was collected mainly through the financial reports publicly available on the website of ASE and on the website of the company.

Exogenous variable: the level of corporate social responsibility disclosure (CSRD): previous studies have used different approaches to measure the extent and level of CSR disclosure. Some studies have used Dowjones sustainability index, others have constructed a sustainability index depending on global reporting initiative standards, following (Suwaidan et al., 2004, Babalola, 2012, Abu farah \& Alkhalaileh, 2016), This paper has constructed CSR disclosure index, the first step was the selection of the CSR index check list which consisted of four dimensions namely are (environmental disclosure, employee information, community involvement and product responsibility dimensions ). The final version of the CSR index check list involved 43 sub items concerning the four main dimensions of CSR practices, Manual content analysis was conducted to measure the CSR disclosure level using dichotomous technique, therefore, if a company disclose an item it scored (1) and (0) otherwise. The total score is derived as a ratio of the full disclosure items to the full items in the check list (43):

$$
\operatorname{CSRD~i,~} \mathrm{t}=\frac{\sum_{l}^{43} \mathrm{D} \mathrm{i}, \mathrm{t}}{43}
$$

Where:

CSRD i,t : corporate social responsibility disclosure score of a firm i in year $t$. 
D: 1 if the item is disclosed 0 otherwise.

\subsubsection{Financial Performance}

The current paper employs two accounting-based measures of financial performance (F.P);

(1) Return on assets (ROA), which has broadly utilized by previous studies. (Mahrani \& Noorlailie, 2018, Marta, 2015, Babalola, 2012), (ROA) is a measure of efficiency which expected to provide effective results (Angelia\&Suryaningsih, 2015). The following equation represents the ROA ratio:

$$
\mathrm{ROA}=\frac{\text { Net Income }}{\text { Total Assets }}
$$

(2) Return on equity (ROE): a measure of profitability used by previous studies (e.g. Ner \& Machdar,2019, Abunassar \&Altwerqi,2021), the ratio of ROE can be derived as follows:

$$
\mathrm{ROE}=\frac{\text { Net profit before tax }}{\text { Equity }}
$$

Endogenous variable: Accounting conservatism is employed as the mediation variable. Following (Ahmed \& Dnellany,2007, Abunassar \&Altwerqi,2021, El-Habashy,2019 ), this study measure accounting conservatism using accruals derived by the following equation:

$$
A C C O N S i, \mathrm{t}=\left(\frac{E B E X T \text { i,t-DEPi,t-OCF } i, t}{T A i, t}\right) \times-1
$$

Where, ACCONS: accrual-based accounting conservatism.

EXBEXT i,t : income before tax and extraordinary items.

DEP $i, t$ : depreciation for company $i$ in year $t$.

OCF $i, t$ : cash flows from operating activities for company $i$ in time $t$.

TA: the Total assets of company I in time $\mathrm{t}$.

\subsection{Data Examination}

In these types of models (PLS-Path model) it is important to ensure the data validity and freedom from errors

\begin{tabular}{|c|c|}
\hline Test & Short description and rules of thumb \\
\hline Missing data & $\begin{array}{l}\text { Values not obtained or lost about an observation, } \\
\text { Missing values should not exceed } 15 \% \text { for an observation, if so the observation may be } \\
\text { deleted, if less than } 5 \% \text { maybe replaced by the mean, otherwise should be deleted using case } \\
\text { wise.for more options see (Hair et.al,2021.p80) }\end{array}$ \\
\hline Outliers & $\begin{array}{l}\text { Extreme values, If erroneously should be corrected, if there is no justification then should be } \\
\text { considered for removal depends on its impact on the results. }\end{array}$ \\
\hline Normal distribution & Kurtosis skewness absolute value should be less than 1 as a proven of normal distribution \\
\hline Composite reliability & $\begin{array}{l}\text { A measure of internal consistency, } 0.70-090 \text { ensures high consistenecy, values between } 0.60 \\
\text { and } 0.70 \text { are acceptable, } 0.40-0.60 \text { considered for removal. }\end{array}$ \\
\hline Discriminant validity & True measure of distinction, cross loading measures \\
\hline Convergent validity & Average variance extract should be higher than 0.50 . \\
\hline
\end{tabular}
(Hair et.al,2021. Table 2 presents some common tests that help maintaining data validity.

Table 2. Common tests of data validity and rules of thumb

The structural model of the study achieved the requirements of data validity for analysis, normal distribution was ensured as the skewness value came within the range -1 and 1 , composite reliability test showed values of 0.75 for CSRD, 0.69 for Financial performance and 1.00 for accounting conservatism. Convergent validity tests showed AVE higher than 0.50 .

\section{Results of PLS-SEM Analysis}

\subsection{The Structural Model Measurements}

The results of PLS analysis was obtained using smart PLS3. Table 3 presents values of $\mathrm{R}^{2}$ and $\mathrm{Q}^{2}$ for the 
endogenous variables, $\mathrm{R}^{2}$ is an indicator of the model explanatory power while $\mathrm{Q}^{2}$ is a measure of the model predictive validity. $\mathrm{R}^{2}$ for accounting conservatism is 0.25 indicating that 25 percent of the change in conservative accounting can be interpreted by CSRD, $\mathrm{R}^{2}$ for financial performance is 29 percent of the variance in financial performance can be interpreted by conservative accounting, $\mathrm{Q}^{2}$ for the two dependent variables is higher than zero which indicates an acceptable predictive validity.

Table 3. Structural Model Measurements

\begin{tabular}{llll}
\hline hypothesis & Endogenous constructs & $\mathbf{R}^{2}$ & $\mathbf{Q}^{2}$ \\
\hline \multirow{2}{*}{ H4 } & Accounting conservatism(ACCONS) & 0.25 & 0.26 \\
& Financial performance(F.P) & 0.29 & 0.29 \\
\hline
\end{tabular}

\subsection{Final Results of PLS Analysis and Discussion}

Table 4 presents the results of hypotheses testing using PLS-path analysis, the results illustrate the direct and indirect effect for the exogenous and endogenous variables.

Table 4. Results of direct and indirect effect

\begin{tabular}{|c|c|c|c|c|c|c|}
\hline \multicolumn{7}{|c|}{ Direct effect } \\
\hline & Independent variable & $\begin{array}{l}\text { Dependent } \\
\text { variable }\end{array}$ & $\begin{array}{l}\text { Path } \\
\operatorname{coefficient}(\beta)\end{array}$ & P-value & $\mathrm{p} \leq 0.05$ & conclusion \\
\hline H1 & CSRD & F.P & 0.34 & 0.01 & yes & accepted \\
\hline $\mathrm{H} 2$ & CSRD & ACCONS & 0.06 & 0.04 & yes & accepted \\
\hline & & & 0.23 & & & \\
\hline $\mathrm{H} 3$ & ACCONS & F.P & & 0.02 & yes & accepted \\
\hline \multicolumn{7}{|c|}{ Indirect effect } \\
\hline & & $\beta$ & p-value & $\mathrm{p} \leq 0.05$ & mediation & Mediation type \\
\hline \multirow{3}{*}{$\mathrm{H} 4$} & $\mathrm{CSRD} \longrightarrow$ F.P & 0.26 & 0.02 & yes & $\begin{array}{l}\text { Yes ( } \beta \text { value decreased but still } \\
\text { significant) }\end{array}$ & $\begin{array}{l}\text { Complimentary } \\
\text { mediation }\end{array}$ \\
\hline & ACCONS & 0.22 & 0.02 & yes & - & - \\
\hline & ACCONS $\longrightarrow$ F.P & 0.48 & 0.01 & yes & - & - \\
\hline
\end{tabular}

\section{H1: The impact of CSRD on financial performance}

The results presented in Table 4 show that the CSRD positively and significantly impact financial performance, proofed by the value of the $\operatorname{coefficient}(\beta=0.34)$ at the level of statistical significance( $\mathrm{p}$-value $=0.01)$ Therefore, increasing the level of CSRD will lead to an increase in profitability, this result can be explained That social responsibility practices improved the company's image and won the investor's appreciation and respect, which was positively reflected on the company's financial performance. These results are coping with the legitimacy theory and the concept of the social contract, which sees that focus attention on the expectations of society and striving to conform to these expectations will be welcomed by the relevant parties, which will be reflected positively on the financial performance. This result also agrees with the stakeholders' theory, which sees that stakeholders are all parties that can affect and affected by the company's operations. This result is supported by the results of previous studies (e.g. Babalola, 2012; Abu Farah \& Alkhalaileh, 2016; Madaleno \& Vieira, 2020).

\section{H2: The impact of CSRD on accounting conservatism}

The results found that CSRD positively and significantly impact accounting conservatism, the $\beta$ value of CSRD is 0.06 at a significance level of ( $\mathrm{p}$-value $=0.04$ ) which is less than 0.05 , thus, hypothesis 2 is accepted, this result implies that Companies that practice social responsibility activities will tend to adopt conservative accounting policies and methods, this conclusion is supported by that found by (Shen et.al, 2019) which concluded that CSR positively affect accounting conservatism. 


\section{H3: The effect of conservative accounting on financial performance}

The coefficient of accounting conservatism variable is 0.23 indicating that accounting conservatism positively affect financial performance, this impact is significant at $(\mathrm{p}$-value $=0.02)$. this result indicate that higher accounting conservatism will be appreciated by investors and creditors and thus reflected in high financial performance, this is supported by those found by (Sana'a, 2016; El-Habashy, 2019; Abunassar \& Altwerqi, 2021).

\section{H4: The impact of CSRD on financial performance via accounting conservatism}

The results presented in table 4 show that CSRD exerts a positive and significant impact on accounting conservatism(the mediation variable), as well as a positive and significant impact on financial performance, this result prove that the mediator variable (accounting conservatism) has a complimentary partial mediation role between CSRD and financial performance, a partial mediation occurs when the direct impact of the exogenous (CSRD) remains significant along with the indirect impact in the mediation model, furthermore, it is a complementary mediation that appears when the indirect effect and direct effect remain significant and in the same direction (Hair et.al,2021,p237). The use of accounting conservatism is an indicator of financial reports quality and thus the quality of profits, which will positively affect the investor's confidence leading to enhance the financial performance. This result is supported by that found by (Shen et.al, 2019) who conclude that CSR practices have a positive impact on the degree of conservative accounting. These effects were positively reflected on the market reaction. The costs of social responsibility activities are normally high; management seeks to compensate those sacrificed resources through adopting more prudent level of conservatism which will be reflected in high information quality which in turn enhances the financial performance.

\section{Conclusion and Recommendation}

Previous studies investigated the effect of CSR disclosure on financial performance, this paper intended to investigate the direct impact of CSR disclosure on financial performance as well as the indirect impact via accounting conservatism as a mediator variable. The results revealed that increasing the CSR disclosure level would enhance the company's profitability. The results also showed that accounting conservatism plays a complementary partial moderating role in this relationship. These results might serve legislators to urge companies to improve the level of CSR disclosure and to practice a prudent level of accounting conservatism. The study recommends that the external auditor evaluate the level of CSR disclosure in the financial reports and to evaluate the level of accounting conservatism in the financial statements. This study used data for the industrial companies only, so it is not possible to generalize these results to other sectors, future studies recommended to include other sectors.

\section{References}

Alshannag, F. M., Basah, M. Y. A., \& Khairi, K. F. (2016). The level of corporate social responsibility disclosure in Jordan. International Journal of Accounting Research, 2(12), 50-64. https://doi.org/10.12816/0033283

Amake, C., \& Akogo, O. (2021). Corporate Social Responsibility and Accrual-Based Earnings Management: Evidence from Nigeria. Mediterranean Journal of Social Sciences, 12, 15. https://doi.org/10.36941/mjss-2021-0040

Angelia, D., \& Suryaningsih, R. (2015). The effect of environmental performance and corporate social responsibility disclosure towards financial performance (Case study to manufacture, infrastructure, and service companies that listed at Indonesia stock exchange). Procedia-Social and Behavioral Sciences, 211, 348-355. https://doi.org/10.1016/j.sbspro.2015.11.045

Babalola, Y. A. (2012). The impact of corporate social responsibility on firms' profitability in Nigeria. European Journal of Economics, Finance and administrative sciences, 45(1), 39-50.

Basu, S. (1997). The conservatism principle and the asymmetric timeliness of earnings1. Journal of accounting and economics, 24(1), 3-37. https://doi.org/10.1016/S0165-4101(97)00014-1

Bozzolan, S., Fabrizi, M., Mallin, C. A., \& Michelon, G. (2015). Corporate social responsibility and earnings quality: International evidence. The International Journal of Accounting, 50(4), 361-396. https://doi.org/10.1016/j.intacc.2015.10.003

Cassel, C., Hackl, P., \& Westlund, A. H. (1999). Robustness of partial least-squares method for estimating latent variable quality structures. Journal of applied statistics, 26(4), 435-446. https://doi.org/10.1080/02664769922322

Deegan, C., \& Unerman, J. (2011). Unregulated corporate reporting decisions: considerations of 
systems-oriented theories. Financial accounting theory. London: McGraw-Hill.

El-Habashy, H. A. (2019). The impact of accounting conservatism on corporate performance indicators in Egypt. International Journal of Business and Management, 14(10), 1-18. https://doi.org/10.5539/ijbm.v14n10p1

Eyad, A. S., \& Murad, M. A. N. (2016). Effect of corporate social responsibility on nonfinancial organizational performance: evidence from Yemeni for-profit public and private enterprises. Social Responsibility Journal, 12(2), 247-262. https://doi.org/10.1108/SRJ-04-2015-0049

Farha, E. A., \& Al-Khalialeh, M. (n.d.). The Relationship between Corporate Social Responsibility's Disclosure and Stock Returns: An Empirical Study of Jordanian Companies Listed on Amman Stock Exchange.

Gangi, F., Mustilli, M., Varrone, N., \& Daniele, L. M. (2018). Corporate social responsibility and banks' financial performance. International Business Research, 11(10), 42-58. https://doi.org/10.5539/ibr.v11n10p42

Gonçalves, T., Gaio, C., \& Ferro, A. (2021). Corporate Social Responsibility and Earnings Management: Moderating Impact of Economic Cycles and Financial Performance. Sustainability, 13, 9969. https://doi.org/10.3390/su13179969

Guo, J., Huang, P., \& Zhang, Y. (2020). Accounting conservatism and corporate social responsibility. Advances in accounting, 51, 100501. https://doi.org/10.1016/j.adiac.2020.100501

Hair Jr, J. F., Hult, G. T. M., Ringle, C. M., \& Sarstedt, M. (2021). A primer on partial least squares structural equation modeling (PLS-SEM). Sage publications. https://doi.org/10.1007/978-3-030-80519-7

Hong, S. (2020). Corporate social responsibility and accounting conservatism. International Journal of Economics and Business Research, 19(1), 1-18. https://doi.org/10.1504/IJEBR.2020.103883

Madaleno, M., \& Vieira, E. (2020). Corporate performance and sustainability: Evidence from listed firms in Portugal and Spain. Energy Reports, 6, 141-147. https://doi.org/10.1016/j.egyr.2020.11.092

Manrique, S., \& Martí-Ballester, C. P. (2017). Analyzing the effect of corporate environmental performance on corporate financial performance in developed and developing countries. Sustainability, 9(11), 1957. https://doi.org/10.3390/su9111957

Marta,K,(2015). The Essence of Corporate Social Responsibility and the Performance of Selected Company, Procedia - Social and Behavioral Sciences, Volume 213, Pages 509-515, ISSN 1877-0428. https://doi.org/10.1016/j.sbspro.2015.11.442

Mohd, N., Farizal, N., \& Zulkepli, N. S. (2020). Accounting Conservatism and Financial Performance: Accountability of Shariah Compliant Companies in Malaysia. Humanities, 8(3), 280-297. https://doi.org/10.18488/journal.73.2020.83.280.297

Nera, M., \& Machdar, N. (2019). Corporate social responsibility disclosure mediates the relationship between corporate governance, and corporate financial performance in Indonesia. Academy of Accounting and Financial Studies Journal, 23, 1-14.

O'Donovan, G. (2002). Environmental disclosures in the annual report: Extending the applicability and predictive power of legitimacy theory. Accounting, Auditing \& Accountability Journal, 15(3), 344-371. https://doi.org/10.1108/09513570210435870

Ortas, E., Álvarez, I., \& Garayar, A. (2015). The environmental, social, governance, and financial performance effects on companies that adopt the United Nations Global Compact. Sustainability, 7(2), 1932-1956. https://doi.org/10.3390/su7021932

Oyewumi, O. R., Ogunmeru, O. A., \& Oboh, C. S. (2018). Investment in corporate social responsibility, disclosure practices, and financial performance of banks in Nigeria. Future Business Journal, 4(2), 195-205. https://doi.org/10.1016/j.fbj.2018.06.004

Park, H. J., \& Ha, M. H. (2020). Corporate social responsibility and earnings transparency: Evidence from Korea. Corporate Social Responsibility and Environmental Management, 27(3), 1498-1508. https://doi.org/10.1002/csr.1922

Platonova, E., Asutay, M., Dixon, R., \& Mohammad, S. (2018). The impact of corporate social responsibility disclosure on financial performance: Evidence from the GCC Islamic banking sector. Journal of Business Ethics, 151(2), 451-471. https://doi.org/10.1007/s10551-016-3229-0

Sana'a, N. M. (2016). The effect of accounting conservatism on Financial Performance Indicators in the 
Jordanian Insurance Companies. Journal of Internet Banking and Commerce, 21(1), 1.

Suwaidan, M. S., Al-Omari, A. M. D., \& Haddad, R. H. (2004). Social responsibility disclosure and corporate characteristics: the case of Jordanian industrial companies. International Journal of Accounting, Auditing and Performance Evaluation, 1(4), 432-447.variable", Asian Journal of Accounting Research, 3(1), 41-60. https://doi.org/10.1504/IJAAPE.2004.006355

Wahba, H., \& Elsayed, K. (2015). The mediating effect of financial performance on the relationship between social responsibility and ownership structure. Future Business Journal, 1(1-2), 1-12. https://doi.org/10.1016/j.fbj.2015.02.001

Wuttichindanon, S. (2017). Corporate social responsibility disclosure - choices of report and its determinants: Empirical evidence from firms listed on the Stock Exchange of Thailand. Kasetsart Journal of Social Sciences, 38(2), 156-162. https://doi.org/10.1016/j.kjss.2016.07.002

\section{Copyrights}

Copyright for this article is retained by the author(s), with first publication rights granted to the journal.

This is an open-access article distributed under the terms and conditions of the Creative Commons Attribution license (http://creativecommons.org/licenses/by/4.0/). 